\title{
COVARIANCE GENETIC ESTIMATES FOR FEATURES TABAPUÃ GROWTH IN BRAZIL
}

\author{
FONSECA, Wéverton José Lima ${ }^{1}$ \\ EVANGELISTA, Amauri Felipe ${ }^{1}$ \\ BORGES, Laylson da Silva ${ }^{1}$ \\ GUERRA, Leandro de Oliveira ${ }^{2}$ \\ VOGADO, Gleissa Mayone Silva ${ }^{2}$ \\ SOUSA, Paulo Henrique Amaral Araújo de ${ }^{1}$ \\ SILVA, Angela Lopes da ${ }^{2}$ \\ SOUSA JÚNIOR, Severino Cavalcante $\mathrm{de}^{3}$
}

SUMMARY: This review aimed todiscuss covariance components for Tabapuã the growth characteristics in Brazil, using random regression models. The random regression models (MRA) make it possible to estimate coefficients of the covariance functions by the method of restricted maximum likelihood. These are suitable for longitudinal data analysis models, because of the deficiencies of conventional methods of quantitative genetic analysis, which are considered phenotypic values inherently continuous processes, as discrete processes. The covariance functions show the statistical correlation between two features of a trajectory at different points of same, ie that present in the arrangement have the same direction and magnitude. With the current concern of cutting bovinocultores regarding the growth of animals, the use of methods or techniques that provide increasingly accurate assessments of genetic parameters to be used in studying the development of animals for meat production is relevant.

Keywords: Genetic covariance, random regression, Zebu.

\section{ESTIMATIVAS DE COVARIÂNCIA GENÉTICA PARA CARACTERÍSTICAS DE CRESCIMENTO DA RAÇA TABAPUÃ NO BRASIL}

\begin{abstract}
RESUMO: Esta revisão teve como objetivo, discorrer os componentes de covariância genética para características de crescimento da raça Tabapuã no Brasil, utilizando modelos de regressão aleatória. Os modelos de regressão aleatória (MRA) possibilitam estimar coeficientes das funções de covariância pelo método da máxima verossimilhança restrita. Estes são adequados para análises de modelos de dados longitudinais, em virtude de suprir as deficiências dos métodos convencionais de análises genéticas quantitativas, os quais se consideram os valores fenotípicos intrinsecamente processos contínuos, como processos discretos. As funções de covariância evidenciam a correlação estatística entre duas características de uma trajetória em pontos diferentes da mesma, ou seja, a disposição que apresentam em possuir a mesma direção e magnitude. Com a atual preocupação dos bovinocultores de corte em relação ao crescimento dos animais, é relevante o uso de métodos ou técnicas que propiciem avaliações cada vez mais acuradas dos parâmetros genéticos que serão utilizados no estudo do desenvolvimento dos animais destinados à produção de carne.
\end{abstract}

Palavras-chave: Covariância genética. Regressão aleatória. Zebu.

\section{INTRODUCTION}

Conventional analysis to estimate covariance components and genetic parameters of the population of animals, growth traits are performed by means of finite-dimensional models.

\footnotetext{
${ }^{1}$ Universidade Federal do Piaui - Mestrando no Programa de Pós Graduação em Ciência Animal/ Teresina - PI

${ }^{2}$ Universidade Federal do Piaui - Graduando em Zootecnia - Campus Cinobelina Elvas - Bom Jesus/Pi

3 Universidade Federal do Piaui - Professor da UFPI Campus Ministro Reis Velloso - Parnaíba/Pi
} 
However, it is necessary to estimate covariance components for obtaining the genetic values and parameters, to choose the methods used in the estimation of covariance components and genetic parameters is essential in genetic evaluations (LACERDA et al., 2014).

The random regression models (MRA), called infinite-dimensional models are being used to estimate the variance components and genetic parameters of beef cattle weights. The MRA have become an alternative pattern for genetic analysis of longitudinal data, where one of the barriers, these designs is related to the availability of memory and computational time for performing genetic assessments on a large scale (SOUSA JÚNIOR et al., 2014).

Thus, the aim with this literature review, presenting the increase in studies of genetic covariance components for Tabapuã the growth characteristics in Brazil using random regression models.

\section{Tabapuã}

The Tabapuã is a Brazilian zebu breed, the result of crosses between the national polled cattle and animals of Indian origin like Nellore and Guzerá. Was in the 1940s, in the municipality of Tabapuã (SP), the race took on the characteristics that endure to this day. The first recorded Tabapuã animal was the bull Tabapuã Ball T-1210, with the RGD n 1 on February 1, 1971 and officially recognized as a breed in 1981. In 2009, about 15,800 animals received genealogical record of birth (RGN) and 7,500 received definitive genealogical register (RGD), representing $3.71 \%$ and $3.56 \%$, respectively, of the total of animals of Zebu breeds registered this year (ABCZ, 2010).

The Tabapuã was officially recognized on January 1, 1981, and the number of records and creators have been increased in recent years due to race have shown, beyond the format polled the conformation of the meat type insured by light and sturdy bone structure, resulting in the production excellent carcasses. The race is being selected for increased weight gain through the breeding program of Zebu (PMGZ) of the Brazilian Association of Zebu Breeders (ABCZ), in partnership with the Animal Science Institute of Sertaozinho where the goal is to identify and select genetically superior animals either by weight gain tests or progeny test.

The Tabapuã is one of those responsible for the great progress made by beef cattle, especially in recent years, which although studied little, has been increasing in Brazil through its precocity, fertility, and high complementarity in crossing with other breeds, especially Nellore. Due to its high productivity and favorable conditions to develop and adapt to the environmental conditions offered by Brazil, the Tabapuã is currently one of the most important, not only for its quantitative aspect, as the evolution that has achieved as race meat production promoter (FERRAZ FILHO et al., 2002). 


\section{Genetic parameters and growth model}

The genetic evaluation of beef cattle growth curve depends on the estimates of genetic parameters for traits of economic interest. So these parameters are reliable, the genetic evaluation methodologies must be correctly applied to the predicted breeding values can be accurate and thus actually represent an effective tool picker in search of genetic progress of the herd (FARIA et al., 2007 ). Genetic values for beef cattle growth characteristics are predicted and the variance components are estimated considering the weight at standard ages as, for example, at birth, weaning, the year and the end using univariate or multicaracterísticas (ALBUQUERQUE and El FARO, 2008).

Much discussion today among geneticists beef cattle is the way to improve the accuracy of existing genetic evaluations (SPIEDEL et al., 2010). Although much of this discussion is focused on incorporating information from DNA markers for current genetic evaluation schemes, increasing the number of usable records also add accuracy to expected progeny differences (DEP's) (SCHAEFFER, 2006; GODDARD and HAYES, 2007). The use of random regression techniques can allow the incorporation of observations taken at any time of the animal's life, which by higher accuracies of the DEP's, would result in increase in genetic gain rate (WILLIAMS et al., 2009).

Characteristics related to animal growth are adopted in breeding programs in beef cattle as selection criteria, because of the compensation of producers be made based on carcass weight (LAUREANO et al., 2011). Features such as weights and weight gains as well as economical and easy to be measured in a large number of individuals have genetic variability Mid magnitude in zebu cattle as Nellore and Tabapuã, promoting acceptable genetic gains (ALBUQUERQUE; MERCADANTE; ELER, 2007; SOUSA JÚNIOR et al., 2010a).

Regarding the designs commonly used for the description of growth curves Santoro et al. (2005) and Mendes et al. (2009) highlight the nonlinear models, in which the biological interpretation of parameters are basically estimated by the upper or weight (asymptotic) of the animals and the level of maturity, which informs the growth rate of the same. In addition, these models describe the growth of the individual throughout his life, to evaluate the genetic and environmental components that affect the shape of the growth curve of the animals.

\section{Regression models shuffle}

The random regression models (MRA) make it possible to estimate coefficients of the covariance functions by the method of restricted maximum likelihood. These are suitable for longitudinal data analysis models, because of the deficiencies of conventional methods of quantitative genetic analysis, which are considered phenotypic values inherently continuous 
processes, as discrete processes. With (MRA), the random regression coefficients as a function of time are obtained for each animal, instead of using the model for repeatability unique feature or characteristic of the multiple model (MEYER, 1998).

In recent years, the MRA has been adopted as standard procedure in relation to the analysis of longitudinal data in animal breeding. Currently lying established methodology has been employed in various domestic species such as beef cattle (ALBUQUERQUE and MEYER, 2001; DIAS et al., 2006); and dairy cattle (EL FARO and ALBUQUERQUE, 2003; ARAÚJO et al., 2006; SOUSA JÚNIOR et al., 2014). The MRA are special cases of covariance functions that allow estimating, directly, the coefficients of the covariance functions by the restricted maximum likelihood method (MEYER and HILL, 1997). For the study of longitudinal data, such as growth characteristic, the use of random regression models allows obtaining genetic parameters at any age within the range considered (SOUSA JÚNIOR et al., 2010b).

Other benefits in the use of MRA are appointed by Boligon et al. (2010), by claiming that these models allow the inclusion of weights of records that usually would be excluded without compromising the assessment of the animal's growth curve. These authors mention that once in some studies with beef cattle, only considered measures of weight after the age of two. However, it was realized that the sooner these steps are taken, the more accurate will be the evaluation of the weight development of individuals.

In addition to research on beef cattle, these models have been used in the modeling features in various animal species of economic interest, as in the study of the growth of pigs (PINHEIRO et al., 2013), of quails (BONAFÉ et al., 2011) and milk production in goats (MENEZES et al., 2011), highlighting this latest research, modeling records for the production of milk test day.

\section{Longitudinal data analysis models}

Among the features of interest for animal breeding are measured several times during the life of the animal, they are considered as longitudinal data. Thus, the simplest model for longitudinal data analysis consists basically in repeatability model, assuming that all the measurements measured over time represent the same feature. Of interest characteristics may be analyzed for animal breeding, measured repeatedly throughout the animal's life, such as monthly milk production and weight gain, these being termed repeated characteristic over time or longitudinal (SOUSA JÚNIOR et al., 2010b).

According to Menezes (2010), the longitudinal characteristics can be analyzed also by multicaracterísticos models, assuming that each weight set for standard ages is a different 
characteristic. Multicaracterísticas genetic evaluations predict breeding values for different ages through the incorporation of genetic and residual covariance between the ages (SPIEDEL et al., 2010). Another important point in this type of analysis is that the number of parameters to be estimated increases sharply with increasing numbers of features (MENEZES, 2010).

With the current concern of cutting bovinocultores regarding the growth of animals, the use of methods or techniques that provide increasingly accurate assessments of genetic parameters to be used in studying the development of animals for meat production is relevant. Such assessments may be carried out by longitudinal data analysis or repeated measurements by the growth curves and the aid of mathematical models linear or non-linear (ESPILOGAN et al., 2013).

Other models traditionally used in longitudinal data evaluation are the repeatability models that consider as one all the characteristics measured on the individual and the multicaracterísticas models, to assume that every step taken is a different characteristic. However, with the advancement of computing and the emergence of new statistical programs, evaluation methods have been developed animal growth offering better biological interpretation and less time for data analysis (IWAISAKI et al., 2005; DIONELLO et al., 2008).

\section{Covariance Functions}

The covariance functions (FC) can be defined as a continuous function that provides the features of covariance measurements at different points of a trajectory (lactation), describing the covariance between measurements taken at certain ages (days in milk) as a function of these ages (VAN DER WERF and SCHAEFFER, 1997). As Meyer and Hill (1997) demonstrated that the covariance function coefficients can be estimated from the ARM. Thus, different functions can be employed to adjust the trajectory over time. Among the parametric functions, we highlight the exponential function Wilmink (WILMINK, 1987) and the logarithmic function of Ali and Schaeffer (ALI and SCHAEFFER, 1987).

The covariance functions show the statistical correlation between two features of a trajectory at different points of same, ie that present in the arrangement have the same direction and magnitude. The determination of the covariance function is always required as performance indicator of the growth curve, for example, at a certain point, or age of the animal (SOUZA and SA, 2008).

The estimated covariance functions (FC) are considered until now, interesting alternatives to work with longitudinal data allow a description of changes in the covariance as a function of time and the prediction variances and covariances for points along the growth curve animal. The (FC) are equivalent of "finite-dimensional" the covariance matrix in a multivariate analysis of 
"finite-dimensional" and may be obtained by matrix of variance and covariance of these models, or from the covariance matrices of the estimated regression coefficients by random regression models (MEYER, 1998).

According to Kirkpatrick and Heckman (1989), three advantages are presented as models of covariance functions over traditional designs multi-characteristics. The first is that the covariance functions produce a description for any point along a continuous scale measures, allowing the covariance measured between ages not be easily obtained by interpolation. Another advantage is that each covariance function has a set of eigenvalues and eigenfunctions that provide information about the direction in which the mean curve (growth, lactation, etc.) are more likely to be modified by selection, since they have greater genetic variance.

\section{CONCLUSIONS}

On this review, it is clear that studies of estimates of components of (co) variance using random regression model is one of the alternatives that is within the animal breeding programs in making genetic ratings, it allows us to select the best animals to be used as a country for future generations. The random regression models (MRA) have come up showing the standard procedure for genetic analysis of longitudinal data over the past decades, enable thus work with measures taken numerous times during the life of an individual, that is repeated in time. The Tabapuã cattle are still poorly studied in Brazil, and its potential may be underestimated due to lack of studies and research on this breed, given the productive characteristics already observed. Therefore, larger studies and efforts should be made to work with Tabapuã cattle are carried out.

\section{REFERENCES}

ABCZ - Associação Brasileira dos Criadores do Zebu. http://www.abcz.org.br/conteudo/tecnica/estatisticas.html. Acessado em 31/10/2010.

ALBUQUERQUE, L. G.; MEYER, K. Estimates of covariance functions for growth from birth to days of age in Nelore cattle. Journal of Animal Science, v.79, p.2776-2789, 2001.

ALBUQUERQUE, L. G.; MERCADANTE, M. E. Z.; ELER, J. P. Aspectos da seleção de Bos indicus para produção de carne. Boletim da Indústria Animal, v.64, p.339-348, 2007.

ALI, T. E.; SCHAEFFER, R. Accounting for covariances among test day milk yields in dairy cows. Canadian Journal of Animal Science, v.67, p.637-644, 1987.

BOLIGON, A. A.et al. Covariance functions for body weight from birth to maturity in Nellore cows. Journal of Animal Science, Champaign, v.88, p.849-859, 2010. 
BONAFÉ, C. M.et al. Heterogeneidade de variância residual em modelos de regressão aleatória na descrição do crescimento de codornas de corte. Revista Brasileira de Zootecnia, v.40, p.2129-2134, 2011.

DIAS, L. T.et al. Estimação de parâmetros genéticos para peso do nascimento aos 550 dias de idade para animais da raça Tabapuã utilizando modelos de regressão aleatória. Revista Brasileira de Zootecnia, v.35, p.1915-1935, 2006.

DIONELLO, N. J. Let al. Estimativas da trajetória genética do crescimento de codornas de corte utilizando modelos de regressão aleatória. Arquivo Brasileiro de Medicina Veterinária e Zootecnia, v.60, p.454-460, 2008.

EL FARO, L.; ALBUQUERQUE, L. G. Utilização de modelos de regressão aleatória para produção de leite no dia do controle, com diferentes estruturas de variâncias residuais. Revista Brasileira de Zootecnia, Viçosa, v.32, p.1104-1113, 2003.

ESPILOGAN, R.et al. Aplicação de modelos não-lineares para descrever a evolução de características de crescimento em bovinos da raça Hereford. Ciência Rural, v.43, p.513-519, 2013.

FARIA, C. U.et al. Bayesian inference in a quantitative genetic study of growth traits in Nelore cattle (Bos indicus). Genetics and Molecular Biology, v. 30, p. 545-551, 2007.

FERRAZ FILHO, P. B.et al. Herdabilidade e correlações genéticas, fenotípicas e ambientais para pesos em diferentes idades de bovinos da raça Tabapuã. Archives of Veterinary Science, v.7, p.65-69, 2002.

GODDARD, M. E.; HAYES, B. J. Genomic selection. Journal of Animal Breeding and Genetics, v. 124, p.323-300, 2007.

IWAISAKI, H.et al. Genetic parameters estimated with multitrait and linear spline-random regression models using Gelbvieh early growth data. Journal of Animal Science, v.83, p.757763, 2005.

KIRKPATRICK, M.; HECKMAN, N. A quantitative genetic model for growth, shape and other infinitedimensional characters. Journal of Mathematical Biology, v.27, p.429-450, 1989.

DIAS LACERDA, J. J.et al. Parâmetros e tendências genéticas para características de crescimento em bovinos da raça Nelore no Estado da Bahia utilizando inferência bayesiana.

Revista Brasileira de Saúde Produção Animal, v.15, p.10-19, 2014.

LAUREANO, M. M. M.et al. Estimativas de herdabilidade e tendências genéticas para características de crescimento e reprodutivas em bovinos da raça Nelore. Arquivo Brasileiro de Medicina Veterinária e Zootecnia, v.63, p.143-152, 2011.

MENDES, P. N.et al. Análise da curva de crescimento difásica de fêmeas Hereford por meio da função não linear de Gompertz. Ciência Animal Brasileira, v.10, p.454-461, 2009.

MEYER, K.; HILL, W.G. Estimation of genetic and phenotypic covariance functions for longitudinal or 'repeated' records by restricted maximum likelihood. Livestock Production Science, v.47, p.185-200, 1997. 
MEYER, K. Estimating covariance functions for longitudinal data using random regression model. Genetics Selection Evolution, v.30, p.221-240, 1998.

MENEZES, R. O. M.; Uso de polinômios segmentados na modelagem de dados longitudinais de ponderal em bovinos da raça Tabapuã. Tese, Universidade Fedral de Viçosa, 2010.

MENEZES, G. R. O.et al. Modelos de regressão aleatória na avaliação da produção de leite em cabras da raça Sanen. Revista Brasileira de Zootecnia, v.40, p.1526-1532, 2011.

PINHEIRO, V. R. et al. Mapeamento de QTL para características de crescimento de suínos por meio de modelos de regressão aleatória. Pesquisa Agropecuária Brasileira, v.48, p.190-196, 2013.

SANTORO, K. R.et al. Uso de funções de covariância na descrição do crescimento de bovinos Nelore criados no Estado de Pernambuco. Revista Brasileira de Zootecnia, v.34, p.2290-2297, 2005. Suplemento.

SCHAEFFER, L. R. Strategy for applying genome-wide selection in dairy cattle. Journal of Animal Breeding and Genetics, v. 123, p.218-223, 2006.

SOUSA JÚNIOR, S. C.et al. Estimação de funções de covariância para características de crescimento da raça Tabapuã utilizando modelos de regressão aleatória. Revista Brasileira de Zootecnia, v.39, p.1037-1045, 2010.

SOUSA JÚNIOR, S. C.et al. Aplicação de modelos de regressão aleatória utilizando diferentes estruturas de dados. Revista Ciência Rural, v.44, p.2058-2063, 2014.

SOUSA, S. F., SÁ, N. C. Sobre a estimação e modelagem de funções covariâncias na colocação por mínimos quadrados. Revista Brasileira de Cartografia, v.1, p.99-110, 2008.

SPIEDEL, S.E.; ENNS, R. M.; CREWS JR, D. H. Genetic analysis of longitudinal data in beef cattle: a review. Genetics and Molecular Research, v. 9, p. 19-33, 2010.

VAN DER WERF, J.; SCHAEFFER, L. Random regression in animal breeding. Ontário: University of Guelf, 1997. 70p.

WILMINK, J. B. M. Adjustment of test-day milk, fat and protein yields for age, season and stage of lactation. Livestock Production Science, v. 16, p.335-348, 1987.

WILLIAMS, J. L.; GARRICK, D. J.; SPEIDEL, S. E. Reducing bias in maintenance energy expected progeny difference by accounting for selection on weaning and yearling weights. Journal of Animal Science, v.87, p.1628-1637, 2009. 